\title{
Relationships between Core Strength, Dynamic Balance and Knee Valgus during Single Leg Squat in Male Junior Athletes
}

(Hubungan antara Kekuatan Teras, Keseimbangan Dinamik serta Kinematik Lutut semasa Mencangkung dengan Sebelah Kaki pada Atlet Muda Lekaki)

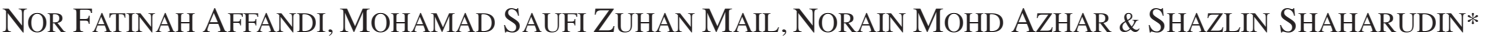

\section{ABSTRACT}

This study was conducted to evaluate the relationships between core strength, dynamic balance and knee kinematics during single leg squat. Core strength helps to improve dynamic balance and muscle coordination between lower and upper extremities, as well as reduce injury risks and muscular strength imbalance. Dynamic balance is the ability to maintain a stable position during dynamic tasks and can be used as a predictor of injury risk factors. Thirty-two statelevel male junior athletes with a normal range of dynamic knee valgus were recruited. The participants went through a series of tests that included Modified Plank Test, Star Excursion Balance Test (SEBT) and Single Leg Squat (SLS) test. Two-dimensional knee frontal plane projection angle (FPPA) during SLS was evaluated at a $60^{\circ}$ knee flexion. There was a statistically significant correlation between distance reached in anteromedial direction and knee FPPA during SLS in the non-dominant leg $(r=0.374, p=0.035)$. There was no significant correlation between duration of plank and knee FPPA during SLS in both dominant and non-dominant legs. The outcomes from this study are important to prevent lower limb injuries in male junior athletes.

Keywords: Biomechanics; dynamic knee valgus; top down kinetic chain; youth athletes

\section{ABSTRAK}

Kajian ini telah dijalankan untuk menilai hubungan antara kekuatan teras, keseimbangan dinamik serta kinematik lutut semasa mencangkung dengan sebelah kaki. Kekuatan teras membantu untuk memperbaiki keseimbangan dinamik dan koordinasi otot antara bahagian atas dan bawah anggota badan, di samping mengurangkan risiko kecederaan dan ketidakseimbangan kekuatan otot. Keseimbangan dinamik ialah kebolehan untuk mengekalkan posisi yang stabil semasa tugas dinamik dan boleh digunakan sebagai satu peramal faktor risiko kecederaan. Tiga puluh dua atlet junior lelaki peringkat negeri yang mempunyai lutut valgus dinamik dalam anggaran normal, telah direkrut. Peserta menjalani satu siri ujian yang merangkumi Ujian Plank Diubahsuai, Ujian Keseimbangan Pergerakan Bintang (SEBT) dan ujian Mencangkung Sebelah Kaki (SLS). Sudut unjuran lutut dua dimensi pada satah depan (FPPA) semasa SLS telah dinilai pada lutut bengkok bersudut $60^{\circ}$. Terdapat korelasi yang signifikan secara statistiknya antara jarak yang dicapai dalam arah anteromedial dan FPPA lutut semasa SLS pada kaki tidak dominan $(r=0.374, p=0.035)$. Tiada korelasi yang signifikan antara tempoh plank dan FPPA lutut semasa SLS pada kedua-dua kaki dominan dan tidak dominan. Hasil daripada kajian ini adalah penting untuk mencegah kecederaan anggota bawah badan dalam kalangan atlet junior lelaki.

Kata kunci: Atlet muda; biomekanik; lutut valgus dinamik; rantaian kinetik atas bawah

\section{INTRODUCTION}

Dynamic balance is considered as the ability to maintain a stable position while performing a task (Winter et al. 1990). On fields, athletes are always exposed to situations where the body balance is dynamically challenged while performing movements such as walking, running, stepping and jumping (Hrysomallis et al. 2006). For example, a dynamically balanced position in soccer can be perturbed either by the opponent or by the player themselves while passing a ball or while changing directions to avoid an opponent (Bhat \& Moiz 2013). According to Hrysomallis (2011), balance ability has a significant effect on athletic performance. Additionally, poor balance has been associated with an increased risk of ankle injury in a number of sports (Hrysomallis 2007).

Core muscles can be defined as a muscular box with the abdominals in the front, paraspinal and gluteals in the back, the diaphragm as the roof, and hip girdle musculature and the pelvic floor at the bottom (Richardson et al. 1999). Core activity is involved in the majority of intense activities such as jumping, running and kicking whereby the core muscles stabilise the spine and trunk during these dynamic motions (Akuthota et al. 2008). Core strength training is widely applied to improve performance and increase physical fitness in healthy individuals, reduce risk of injuries in athletes and alleviate pain among low back pain patients 
(Atikah et al. 2015; Sekendiz et al. 2010; Tse et al. 2005). Furthermore, fatigue of these core muscles may cause a decreased dynamic stability of the trunk and loss of balance control (Davidson et al. 2004). Hence, core strength is considered as an important component in ensuring good performance in athletes. Core strength training may help in improving dynamic balance and muscle coordination between the lower and upper extremities (Ozmen \& Aydogmus 2016), as well as reducing muscular strength imbalances and preventing lower limb and knee joint injuries (Hewett et al. 2009; Leetun et al. 2004). Stickler et al. (2015) noted that core strength, which was evaluated using the isometric side-lying plank test, was positively associated with knee valgus. Specifically, a 10\% change in core strength normalised to body weight would result in a $1.79^{\circ}$ improvement in knee valgus (Stickler et al. 2015) which is related to the top-down (i.e. proximal origins) kinetic chain of knee valgus. Additionally, Zazulak et al. (2007) reported that impaired trunk proprioception and control are predictors of knee injury in female athletes.

The single leg squat (SLS) is a clinical test to examine lower extremity alignment and may be helpful in identifying faulty movement patterns of the trunk, pelvis, and lower extremity (Khuu et al. 2016). SLS test is a valid and reliable measurement to predict knee injuries such as anterior cruciate ligament (ACL) tear and patellofemoral pain syndrome (PFPS) (Munro et al. 2012). In many daily activities, the position of the single limb stance can be seen while walking and running, or in sports activities such as hockey, football, rugby and skiing (Claiborne et al. 2006).

Although poor balance has been suggested as a risk factor for injury, only few studies have examined this relationship. Moreover, the relationship between core strength and knee valgus during SLS was elaborately researched in healthy females (Stickler et al. 2015). However, to the best of our knowledge, the relationship has not been determined yet among male junior athletes. Therefore, the purpose of the present study was to evaluate the relationship between core strength and dynamic balance and knee frontal plane projection angle (FPPA) during SLS in male junior athletes.

\section{MATERIALS AND METHODS}

The present study was a cross-sectional study. Thirtytwo state-level male junior athletes aged between 13 to 18 years old with normal body mass index (BMI) and free from any musculoskeletal injury at the time of data collection were recruited. The classification of BMI for adolescents was in accordance with the standards from World Health Organization (2004). The protocol of this study was approved by the research ethical committee from Universiti Sains Malaysia (USM/JEPeM/17020116) and in compliance with the Declaration of Helsinki. Participants' consent and their guardian's assent were obtained prior to data collection. All participants were recruited voluntarily. Through drop vertical jump as a screening test, only participants with a normal range of dynamic knee valgus were included in the present study. The normal range of dynamic knee valgus during drop vertical jump is $3^{\circ}$ to $8^{\circ}$ for males (Munro et al. 2012) which was quantified using two-dimensional motion capture and analysis.

Participants were asked to wear tights for ease of motions and accuracy of data collection. They were advised to have enough sleep (at least six hours) the night prior of data collection session, take their meal and avoid caffeine at least two hours before the tests. Participants were also asked to provide information about their medical history, other medical conditions and medications taken. The anthropometry measurements of standing height, body weight, fat percentage and the length of leg segments were taken before the tests. Body weight $(\mathrm{kg})$ and height (m) were measured with a digital medical scale (Seca 769, Hamburg, Germany). The length of the leg segments was measured with a measuring tape. Leg length was quantified as the distance (in $\mathrm{cm}$ ) from the anterior superior iliac spine (ASIS) to the centre of the ipsilateral medial malleolus with the participant in supine and standing positions.

All participants went through a series of tests that included Modified Plank Test, Star Excursion Balance Test (SEBT) and Single Leg Squat (SLS) test. Prior to the tests, participants warmed up by cycling on an ergometer (Cybex Inc., Ronkonkoma, NY, USA) at 60 RPM with 50 watts for five minutes. The Modified Plank Test measured the core strength of the participants (Tong et al. 2014). The participants started the test by holding a basic plank position, with the elbows right beneath the shoulders while forearms and toes were placed on the floor. The test was conducted with incremental difficulty stages which followed the protocol presented by Tong et al. (2014). At the first stage, participants had to hold the normal plank position for $30 \mathrm{~s}$. Then, participants had to lift their right hand and hold for $15 \mathrm{~s}$. Next, they had to lift their left hand and hold for $15 \mathrm{~s}$. Then, they had to lift their right leg from the ground for $15 \mathrm{~s}$ and return to the basic plank position. The same position was repeated for the left leg. For the last two stages, participants had to lift their right hand and left leg off the ground for $15 \mathrm{~s}$ and return to the basic plank position and repeat the same position with their left hand and right leg. Throughout the test, participants should maintain a proper plank posture whereby the body must be in a straight line. If the hips were out of position or any other body parts other than the forearms and the toes touched the floor, the test was attenuated. The duration of participants successfully holding the plank position before breaking their posture or dropping on the floor was recorded and indicated their level of core strength (Jaapar \& Shaharudin 2019).

The function of the Star Excursion Balance Test (SEBT) is to assess dynamic balance (Gribble \& Hertel 2003). The testing grid consisted of eight lines, each 120 $\mathrm{cm}$ in length extending from a common point at $45^{\circ}$ angle increments. The eight lines were labelled according to directions: Anterolateral (AL), anterior (ANT), anteromedial (AM), medial (MD), posteromedial (PM), posterior (PO), 
posterolateral (PL), and lateral (LAT). The middle of the grid was marked with a small dot to indicate the place to put the stance foot over during testing.

Before testing, participants were given three minutes to familiarise themselves with the SEBT grid by reaching in each direction for each leg. Next, they performed the test with their dominant leg as the stance leg. The dominant leg was determined as the leg with which the participant would kick a ball (Graci et al. 2012). They stood barefoot at the centre of the grid. Participants had to reach along each direction line as far as possible using their contralateral leg. Participants were not allowed to use the reach foot as support to maintain balance and upright posture. Ten seconds of rest were provided between individual reach trials (Hertel et al. 2006). The test was repeated with the non-dominant leg as the stance leg. The mean of the reach distances for three trials in each direction was calculated. Then, the mean reach distances were normalised with the participant's leg length to obtain the ratio, which was further expressed in percentage whereby a greater percentage indicated better dynamic stability in the tested direction. The normalisation of reach distance to leg length of each participant was crucial to eliminate the differences due to leg length variability across participants (Abd Rahman \& Shaharudin 2018; Gribble \& Hertel 2003; Jaapar \& Shaharudin 2019).

The SLS test followed the protocol described by Stickler et al. (2015). Prior to the test, a goniometer (Sam's International, India) was used to determine the $60^{\circ}$ of knee flexion during a double leg squat. An adjustable plinth was set at the height of the ischial tuberosity during double limb squat to denote the desired depth (i.e. $60^{\circ}$ of knee flexion) (Stickler et al. 2015). Then, participants placed their hands on their hips and stood on one limb, while the opposite limb had to flex to $90^{\circ}$. By using the stance leg, they performed a squat with $60^{\circ}$ of knee flexion and then returned to a fully extended knee position (Stickler et al. 2015). Five trials of SLS were conducted. During the SLS test, a metronome app, JY Fitness Timer (Alphapod, ver 1.0.14, Malaysia) was set at 60 beats per minute to provide the desired movement speed. Participants were requested to follow the tempo guided by the metronome which was $5 \mathrm{~s}$ of lowering and $5 \mathrm{~s}$ of returning to standing (Stickler et al. 2015). There were no directions given regarding the squat form other than to touch the plinth with the participant's buttocks to indicate $60^{\circ}$ of knee flexion and to keep the opposite limb away from the ground, without any support from the upper limb (Stickler et al. 2015). The test was repeated with the non-dominant leg as the stance leg.

A digital camera (SONY HDR-CX240, Japan) was placed $2.0 \mathrm{~m}$ at the front of the participants to capture their motion during the SLS test. Its height was aligned approximately to the level of the participants' pelvis (Stickler et al. 2015). Video recordings were made at 25 frames per second at a resolution of $800 \times 600$ pixels. Two-dimensional (2D) video analysis (SiliconCoach, version 8 , The Tarn Group) was applied for analysing the SLS, which was shown as a clinically feasible and reliable method of evaluating knee valgus (Munro et al. 2012). Moreover, 2D is valid for frontal plane knee kinematics when compared to threedimensional analysis (McLean et al. 2005). The knee FPPA was calculated as the intersection between a line created by the ASIS and knee marker and another line created by the knee and ankle marker (Munro et al. 2012). For analysis, neutral alignment was considered at $0^{\circ}$, negative values represented valgus alignment, and positive values represented varus alignment (Stickler et al. 2015).

Distribution of data was checked using the ShapiroWilk test. Correlations between knee FPPA during SLS and core strength and dynamic balance were evaluated using Pearson correlation coefficients. The significance level was set at $p<0.05$. The strength of the correlation coefficients was based on the scale as stated by Portney and Watkins (2000) whereby $0.00-0.25$ indicated little or no relationship, $0.25-0.50$ indicated fair relationship, 0.50-0.75 indicated moderate to good relationship, and above 0.75 indicated good to excellent relationship. All data analyses were performed using statistical software (SPSS version 22, Chicago, IL).

\section{RESULTS AND DISCUSSION}

The physical characteristics of participants are presented in Table 1.

TABLE 1. Physical characteristics of participants $(N=32)$

\begin{tabular}{lc}
\hline Physical characteristics & Mean \\
\hline Mass $(\mathrm{kg})$ & $55.08(6.20)$ \\
Height $(\mathrm{cm})$ & $165.00(7.19)$ \\
Body Mass Index (BMI) $\left(\mathrm{kg} / \mathrm{m}^{2}\right)$ & $20.40(1.79)$ \\
Body fat percentage $(\%)$ & $18.53(6.51)$ \\
Dominant knee FPPA during SLS $\left(^{\circ}\right)$ & $8.14(4.17)$ \\
Non-dominant knee FPPA during SLS $\left(^{\circ}\right)$ & $7.80(4.41)$ \\
\hline
\end{tabular}

values are presented in mean (standard deviation)

The average plank duration $($ mean $=113.37, \mathrm{SD}=$ $19.96 \mathrm{~s}$ ) evaluated from the Modified Plank Test indicated the core strength of the participants. However, core strength was not significantly correlated to knee FPPA during SLS on the dominant leg $(r=-0.308, p=0.086)$ and knee FPPA during SLS on the non-dominant leg $(r=-0.068, p=0.713)$.

There was a statistically significant correlation between distance reached in the anteromedial direction of the non-dominant leg (NDAM) and knee FPPA during SLS in the non-dominant leg $(r=0.374, p=0.035)$ (Table 2). For the dominant leg, no statistically significant correlation was observed between knee FPPA during SLS and dynamic balance variables (Table 3). Moreover, no statistically significant correlation between core strength and each direction of SEBT was observed (Table 4).

No significant correlation was observed between core strength and knee FPPA during SLS in both dominant and non-dominant legs among male junior athletes who were screened for a normal range of dynamic knee valgus. 
TABLE 2. Correlation between dynamic balance tested in eight directions of Star Excursion Balance Test (SEBT) and knee FPPA during single leg squat for non-dominant leg $(\mathrm{N}=32)$

\begin{tabular}{lccc}
\hline $\begin{array}{l}\text { Direction of reach in SEBT } \\
\text { for non-dominant leg }\end{array}$ & Normalised reach distance & $\mathrm{R}$ & $\mathrm{p}$ value \\
\hline Anterior (NDANT) & $122.99(24.05)$ & 0.182 & 0.317 \\
Anteromedial (NDAM) & $132.84^{*}(28.91)$ & 0.374 & 0.035 \\
Medial (NDMD) & $139.56(20.92)$ & 0.308 & 0.087 \\
Posteromedial (NDPM) & $142.29(21.42)$ & 0.263 & 0.146 \\
Posterior (NDPO) & $133.45(19.06)$ & 0.301 & 0.094 \\
Posterolateral (NDPL) & $124.96(19.49)$ & 0.179 & 0.327 \\
Lateral (NDLAT) & $109.49(23.74)$ & -0.096 & 0.601 \\
Anterolateral (NDAL) & $112.08(20.28)$ & -0.096 & 0.601 \\
\hline
\end{tabular}

*significant at $\mathrm{p}<0.05$ level, values are presented in mean (standard deviation)

TABLE 3. Correlation between dynamic balance tested in eight directions of Star Excursion Balance Test (SEBT) and knee FPPA during single leg squat for dominant leg $(\mathrm{N}=32)$

\begin{tabular}{lccc}
\hline $\begin{array}{l}\text { Direction of reach in SEBT } \\
\text { for dominant leg }\end{array}$ & Normalised reach distance & $\mathrm{R}$ & $\mathrm{p}$ value \\
\hline Anterior (DANT) & $126.32(14.68)$ & 0.081 & 0.658 \\
Anterolateral (DAL) & $140.03(18.21)$ & 0.051 & 0.783 \\
Lateral (DLAT) & $144.23(24.33)$ & 0.100 & 0.585 \\
Posterolateral (DPL) & $143.62(22.84)$ & -0.128 & 0.485 \\
Posterior (DPO) & $135.16(20.89)$ & -0.191 & 0.294 \\
Posteromedial (DPM) & $124.43(27.34)$ & 0.081 & 0.660 \\
Medial (DMD) & $112.08(23.60)$ & -0.143 & 0.434 \\
Anteromedial (DAM) & $110.31(18.56)$ & -0.076 & 0.678 \\
\hline
\end{tabular}

values are presented in mean (standard deviation)

TABLE 4. Correlation between core strength and dynamic balance tested in eight directions of Star Excursion Balance Test (SEBT) for dominant and non-dominant legs $(\mathrm{N}=32)$

\begin{tabular}{lcc}
\hline Direction of reach in SEBT & $\mathrm{R}$ & $\mathrm{p}$ value \\
\hline Dominant leg: & & \\
$\quad$ Anterior (DANT) & -0.238 & 0.189 \\
Anterolateral (DAL) & -0.317 & 0.078 \\
Lateral (DLAT) & -0.202 & 0.267 \\
Posterolateral (DPL) & 0.072 & 0.697 \\
Posterior (DPO) & -0.240 & 0.185 \\
Posteromedial (DPM) & 0.228 & 0.209 \\
Medial (DMD) & 0.028 & 0.879 \\
Anteromedial (DAM) & -0.062 & 0.737 \\
& & \\
Non-dominant leg: & & \\
Anterior (NDANT) & -0.235 & 0.196 \\
Anteromedial (NDAM) & -0.119 & 0.517 \\
Medial (NDMD) & -0.146 & 0.426 \\
Posteromedial (NDPM) & -0.121 & 0.508 \\
Posterior (NDPO) & -0.106 & 0.563 \\
Posterolateral (NDPL) & -0.142 & 0.437 \\
Lateral (NDLAT) & -0.087 & 0.636 \\
Anterolateral (NDAL) & -0.207 & 0.255 \\
\hline
\end{tabular}

values are presented in mean (standard deviation) 
Initially, we hypothesised that there is an association between core strength and knee FPPA during SLS. The core muscles are the foundation of kinetic chain which are responsible for facilitating the transfer of torque and momentum between lower and upper extremities for gross motor tasks of daily living, exercise, and sports (Akuthota \& Nadler 2004; Behm et al. 2010; Kibler et al. 2006). However, our contradictory results could be due to the gender and fitness level of the participants. Anderson et al. (2014) stated that men have greater abdominal strength and endurance than women. Additionally, Leetun et al. (2004) found that males performed better in extension and side plank tests compared to females.

Core stability played an important role in injury prevention because decreased lumbo-pelvic stability is correlated with a higher rate of lower-extremity injuries, particularly among females (Borghuis et al. 2008). Moreover, lack of core stability might lead to increased strain on the knee ligaments (Borghuis et al. 2008). Furthermore, athletes with decreased neuromuscular control of the core musculature, measured during sudden force release tasks and trunk repositioning, are at an increased risk of knee injury (Bandyopadhyay \& Shaharudin 2009; Zazulak et al. 2007). Hibbs et al. (2008) found that weakness and inappropriate recruitment of the trunk and abdominal muscles might cause spinal instability, thus increased the risk of injuries to the core muscles, knee or hip joints during movements.

Star Excursion Balance Test (SEBT) is a clinical test to measure dynamic balance performance. It involves lower extremity reaching task in eight directions that challenge one's postural control, strength, range of motion and stability of the contralateral stance limb (Hertel et al. 2006). It was found that the visual approximation of the maximal reach distance during SEBT is a valid and accurate measurement (Bastien et al. 2014).

For dynamic balance, only the distance reached in the anteromedial direction of the non-dominant leg (NDAM) and knee FPPA during SLS of the non-dominant leg showed a statistically significant positive correlation. The correlation indicated that, for the non-dominant leg as the stance leg, the knee will become more valgus during SLS with greater distance reach in the direction of anteromedial in SEBT. This relationship could be due to similar muscle activation of the stance leg during SLS and reaching in anteromedial direction with more obvious muscle activity in the nondominant leg. Recently, Uebayashi et al. (2019) observed that the knee valgus angle was significantly greater in the valgus group (i.e. screened through single leg landing test) than the control group in anterior, anteromedial, anterolateral, medial and posteromedial directions of SEBT. They concluded that augmented knee valgus angle in those directions during SEBT may be considered as poor alignment which may cause non-contact ACL injury (Uebayashi et al. 2019). However, the study involved healthy adult females who were tested on their dominant leg only, whereby two-thirds of athletes who visited outpatient orthopaedic clinic suffered a non-contact ACL injury at their non-dominant legs (Brophy et al. 2010). To the best of our knowledge, currently, studies that evaluated the relationship between knee FPPA during SLS and dynamic balance, particularly in male athletes, are non-existent for comparison.

Davidson et al. (2004) stated that trunk muscle fatigue may lead to decreased dynamic stability of the trunk and loss of balance control. Kahle and Gribble (2009) suggested that abdominal muscles that stabilise the lumbar spine may provide increased reach distance during SEBT by supporting the lower extremity movements. However, we did not find any significant association between dynamic balance in all tested directions of SEBT and core strength (Table 4). The discrepancy of our findings from previous studies could be due to the gender and fitness level of the participants, screening test conducted to exclude those with excessive dynamic knee valgus and type of tests used to evaluate core strength.

An eight-year study among junior elite females found greater risk of injury in the youngest group of players (under age 15) compared with the oldest group (under 19) (Le Gall et al. 2008). In the present study, our participants were aged between 13-18 years old. Although they are male athletes, they may have increased risks of lower limb injuries due to their age. According to Frisch et al. (2009), adolescent athletes are more susceptible to injury than younger prepubescent athletes due to rapid growth of muscle mass and increased movement velocity and power which may influence risk perception and self-control. Moreover, due to the possibility of lifelong consequences of sports injuries and associated economic burden (Frisch et al. 2009), more research should be directed to identify modifiable risk factors of lower limb injuries among junior athletes.

The findings of the current study may be limited to the studied population. Three-dimensional analysis of SLS may provide more insights regarding lower limb biomechanics during this motion (Mohd Azhar et al. 2019). Additionally, analysis on muscle synergies during SLS may elucidate the coordination and motor control involved during the motion (Shaharudin et al. 2014). Furthermore, instead of using field tests such as the Modified Plank Test, isokinetic device could be utilised to quantify core strength. Representations of participants from various sports at multiple competitive levels could enhance our understanding regarding the relationships between core strength, dynamic balance and knee FPPA during SLS. Furthermore, only participants with a normal range of dynamic knee valgus were included in the present study which may explain the lack of significant correlations.

\section{CONCLUSION}

In male junior athletes with a normal range of dynamic knee valgus, no significant correlations were observed between core strength and knee FPPA during SLS in both dominant and non-dominant legs. Furthermore, there were no significant correlations between dynamic balance and 
knee FPPA during SLS in both dominant and non-dominant legs except for balance in the anteromedial direction of the non-dominant leg. Hence, training of dynamic balance particularly in the anteromedial direction of the non-dominant leg, may assist in reducing the risk of knee injury among male junior athletes.

\section{ACKNOWLEDGEMENTS}

The authors acknowledged the contributions made by the participants, coaches, personnel of Exercise \& Sports Science Programme, School of Health Sciences, Universiti Sains Malaysia to the completion of the research project. The study was funded by MOHE Fundamental Research Grant Scheme (203/PPSP/6171165), MONSPACE Multinational Corp Exercise is Medicine Research Grant (P174-5/UTs214(18)) and Universiti Sains Malaysia Bridging-Incentive Grant (304/PPSK/6316464).

\section{REFERENCES}

Abd Rahman, N.A. \& Shaharudin, S. 2019. Comparison of skills and lower limb biomechanics of female futsal players at collegiate and club levels. Malaysian Journal of Movement, Health \& Exercise 7(2): 177-194.

Akuthota, V. \& Nadler, S.F. 2004. Core strengthening. Archives of Physical Medicine and Rehabilitation 85: 86-92.

Akuthota, V., Ferreiro, A., Moore, T. \& Fredericson, M. 2008. Core stability exercise principles. Current Sports Medicine Reports 7(1): 39-44.

Anderson, A., Hoffman, J., Johnson, B., Simonson, A. \& Urquhart, L. 2014. Core Strength Testing: Developing Normative Data for Three Clinical Tests. https://sophia.stkate. edu/dpt_papers/32. Accessed on 18 March 2018.

Atikah, C.W., Nihayah, M., Leonard, J.H., Omar, B., Noor Ibrahim, M.S., Zurkarnain, M.K., Jamri, M. \& Wan Mohd Noor, I. 2015. A cross-sectional evaluation on physical fitness of Malaysian firefighters. Sains Malaysiana 44(10): 1461-1466.

Bandyopadhyay, A. \& Shaharudin, S. 2009. Anterior cruciate ligament injuries in soccer players: An overview. International Journal of Sports Science and Engineering 3(1): 50-64.

Bastien, M., Moffet, H., Bouyer, L., Perron, M., Hébert, L.J. \& Leblond, J. 2014. Concurrent and discriminant validity of the Star Excursion Balance Test for military personnel with lateral ankle sprain. Journal of Sport Rehabilitation 23(1): 44-55.

Behm, D.G., Drinkwater, E.J., Willardson, J.M. \& Cowley, P.M. 2010. The use of instability to train the core musculature. Applied Physiology, Nutrition, and Metabolism 35(1): 91108.

Bhat, R. \& Moiz, J.A. 2013. Comparison of dynamic balance in collegiate field hockey and football players using star excursion balance test. Asian Journal of Sports Medicine 4(3): 221-229.

Borghuis, J., Hof, A.L. \& Lemmink, K.A. 2008. The importance of sensory-motor control in providing core stability: Implications for measurement and training. Sports Medicine 38(11): 893-916.

Brophy, R., Chiaia, T., Maschi, R., Dodson, C., Oh, L., Lyman, S. \& Williams, R. 2009. The core and hip in soccer athletes compared by gender. International Journal of Sports Medicine 30(9): 663-667.

Claiborne, T.L., Armstrong, C.W., Gandhi, V. \& Pincivero, D.M. 2006. Relationship between hip and knee strength and knee valgus during a single leg squat. Journal of Applied Biomechanics 22(1): 41-50.

Davidson, B.S., Madigan, M.L. \& Nussbaum, M.A. 2004. Effects of lumbar extensor fatigue and fatigue rate on postural sway. European Journal of Applied Physiology 93(1): 183-189.

Frisch, A., Croisier, J.L., Urhausen, A., Seil, R. \& Theisen, D. 2009. Injuries, risk factors and prevention initiatives in youth sport. British Medical Bulletin 92: 95-121.

Graci, V., Van Dillen, L.R. \& Salsich, G.B. 2012. Gender differences in trunk, pelvis and lower limb kinematics during a single leg squat. Gait \& Posture 36(3): 461-466.

Gribble, P.A. \& Hertel, J. 2003. Considerations for normalizing measures of the star excursion balance test. Measurement in Physical Education and Exercise Science 7(2): 89-100.

Hertel, J., Braham, R.A., Hale, S.A. \& Olmsted-Kramer, L.C. 2006. Simplifying the star excursion balance test: analyses of subjects with and without chronic ankle instability. Journal of Orthopaedic \& Sports Physical Therapy 36(3): 131-137.

Hewett, T.E., Torg, J.S. \& Boden, B.P. 2009. Video analysis of trunk and knee motion during non-contact anterior cruciate ligament injury in female athletes: Lateral trunk and knee abduction motion are combined components of the injury mechanism. British Journal of Sports Medicine 43(6): 417422.

Hibbs, A.E., Thompson, K.G., French, D., Wrigley, A. \& Spears, I. 2008. Optimizing performance by improving core stability and core strength. Sports Medicine 38(12): 995-1008.

Hrysomallis, C. 2007. Relationship between balance ability, training and sports injury risk. Sports Medicine 37(6): 547556.

Hrysomallis, C. 2011. Balance ability and athletic performance. Sports Medicine 41(3): 221-232.

Hrysomallis, C., McLaughlin, P. \& Goodman, C. 2006. Relationship between static and dynamic balance tests among elite Australian Footballers. Journal of Science and Medicine in Sport 9(4): 288-291.

Jaapar, S.H.Z. \& Shaharudin, S. 2019. Effects of load carrying training on core strength, balance and jumping mechanics of female reserve officer training unit cadets. Malaysian Journal of Movement, Health \& Exercise 8(1): 111-121.

Kahle, N.L. \& Gribble, P.A. 2009. Core stability training in dynamic balance testing among young, healthy adults Athletic Training and Sports Health Care 1(2): 65-73.

Khuu, A., Foch, E. \& Lewis, C.L. 2016. Not all single leg squat are equal: Biomechanical comparison of three variations. International Journal of Sports Physical Therapy 11(2): 201-211.

Kibler, W.B., Press, J. \& Sciascia, A. 2006. The role of core stability in athletic function. Sports Medicine 36(3): 189-198.

Leetun, D.T., Ireland, M.L., Willson, J.D., Ballantyne, B.T. \& Davis, I.M. 2004. Core stability measures as risk factors for lower extremity injury in athletes. Medicine \& Science in Sports \& Exercise 36(6): 926-934.

Le Gall, F., Carling, C. \& Reilly, T. 2008. Injuries in young elite female soccer players: An 8-season prospective study. The American Journal of Sports Medicine 36(2): 276-284.

McLean, S.G., Walker, K., Ford, K., Myer, G., Hewett, T. \& Van den Bogert, A.J. 2005. Evaluation of a two dimensional 
analysis method as a screening and evaluation tool for anterior cruciate ligament injury. British Journal of Sports Medicine 39(6): 355-362.

Mohd Azhar, N., Affandi, N.F., Mail, M.S.Z. \& Shaharudin, S. 2019. The effects of foot position on lower extremity kinematics during single leg squat among adolescent male athletes. Journal of Taibah University Medical Sciences 14(4): 343-349.

Munro, A., Herrington, L. \& Carolan, M. 2012. Reliability of 2-dimensional video assessment of frontal-plane dynamic knee valgus during common athletic screening tasks. Journal of Sport Rehabilitation 21(1): 7-11.

Ozmen, T. \& Aydogmus, M. 2016. Effect of core strength training on dynamic balance and agility in adolescent badminton players. Journal of Bodywork and Movement Therapies 20(3): 565-570.

Portney, L.W.M. \& Watkins, M. 2008. Foundations of Clinical Research: Applications to Practice. 3rd ed. New Jersey: Prentice Hall.

Richardson, C., Jull, G., Hodges, P., Hides, J. \& Panjabi, M.M. 1999. Therapeutic Exercise for Spinal Segmental Stabilization in Low Back Pain: Scientific Basis and Clinical Approach. Edinburgh: Churchill Livingstone.

Sekendiz, B., Cug, M. \& Korkusuz, F. 2010. Effects of Swissball core strength training on strength, endurance, flexibility, and balance in sedentary women. The Journal of Strength \& Conditioning Research 24(11): 3032-3040.

Shaharudin, S., Zanotto, D. \& Agrawal, S. 2014. Muscle synergy during Wingate anaerobic rowing test of collegiate rowers and untrained subjects. International Journal of Sports Science 4(5): 165-172.

Stickler, L., Finley, M. \& Gulgin, H. 2015. Relationship between hip and core strength and frontal plane alignment during a single leg squat. Physical Therapy in Sport 16(1): 66-71.
Tong, T.K., Wu, S. \& Nie, J. 2014. Sport-specific endurance plank test for evaluation of global core muscle function. Physical Therapy in Sport 15(1): 58-63.

Tse, M.A., McManus, A.M. \& Masters, R.S. 2005. Development and validation of a core endurance intervention program: Implications for performance in college-age rowers. The Journal of Strength \& Conditioning Research 19(3): 547-552.

Uebayashi, K., Akasaka, K., Tamura, A., Otsudo, T., Sawada, Y., Okubo, Y.\& Hall, T. 2019. Characteristics of trunk and lower limb alignment at maximum reach during the Star Excursion Balance Test in subjects with increased knee valgus during jump landing. PLoS ONE 14(1): e211242.

Winter, D.A., Patla, A.E. \& Frank, J.S. 1990. Assessment of balance control in humans. Journal of Medical Progress Through Technology 16(1-2): 31-51.

Zazulak, B.T., Hewett, T.E., Reeves, N.P., Goldberg, B. \& Cholewicki, J. 2007. Deficits in neuromuscular control of the trunk predict knee injury risk a prospective biomechanicalepidemiologic study. The American Journal of Sports Medicine 35(7): 1123-1130.

Exercise \& Sports Science Programme

School of Health Sciences

Universiti Sains Malaysia

16150 Kota Bharu Kelantan Darul Naim

Malaysia

*Corresponding author; email: shazlin@usm.my

Received: 6 November 2018

Accepted: 23 September 2019 